\title{
Virus Quantification, Flowering, Yield, and Fruit Quality in Tropical Pumpkin (Cucurbita moschata Duchesne) Genotypes Susceptible or Resistant to Two Potyviruses
}

\author{
Wilfredo Seda-Martínez and Linda Wessel-Beaver \\ Department of Agroenvironmental Sciences, University of Puerto Rico at \\ Mayagüez, P.O. Box 9000, Mayagüez, PR 00681-9000
}

\section{Angela Linares-Ramírez \\ Puerto Rico Agricultural Experiment Station, University of Puerto Rico, HC 02, Box11656, Lajas, PR 00667}

\section{Jose Carlos V. Rodrigues \\ Puerto Rico Agricultural Experiment Station, University of Puerto Rico, South Botanical Garden, 1193 Guayacan Street, San Juan, PR 00926}

Additional index words. cucurbits, disease resistance, Papaya ringspot virus, squash, Zucchini yellow mosaic virus

Abstract. Infecting cucurbits around the world, Papaya ringspot virus (PRSV) and Zucchini yellow mosaic virus (ZYMV) are members of the genus Potyvirus and family Potyviridae. Tropical pumpkin is grown globally in the lowland humid tropics. In Puerto Rico, tropical pumpkin is the second most important vegetable crop in economic value. In trials in Puerto Rico in 2016 and 2017, susceptible genotypes 'Waltham', Mos166, 'Taína Dorada' (2016 only), 'Soler' with moderate resistance to ZYMV, and resistant 'Menina' and 'Nigerian Local' were inoculated with PRSV and ZYMV and evaluated in the greenhouse and field. Mockinoculated (buffer) controls were included. Puerto Rico strains of PRSV and ZYMV were originally collected from plants of Cucurbita moschata in Puerto Rico. Presence of virus was determined by Double Antibody Sandwich (DAS) enzyme-linked immunosorbent assay (ELISA) and symptom severity was evaluated on a 0 to 5 scale in both trials. Days to anthesis of first staminate and pistillate flower were recorded for each plot. Number of fruits, fruit weight per plant, average fruit weight, fruit and mesocarp diameter, mesocarp color, ${ }^{\circ}$ Brix, and percentage dry matter were measured in 2017. 'Waltham', Mos166, 'Taína Dorada', and 'Soler' tested positive for PRSV when inoculated with PRSV and positive for ZYMV when inoculated with ZYMV. For both PRSV and ZYMV, symptom severity was less (severity =0) in resistant genotypes 'Menina' and 'Nigerian Local' than in all other genotypes. 'Soler' inoculated with ZYMV exhibited less symptom severity than that of susceptible genotypes. The degree of symptom severity of 'Soler' inoculated with PRSV was similar to susceptible genotypes. Symptom severity in plants inoculated with ZYMV was generally greater than when inoculated with PRSV. Compared with controls, yield per plant was unaffected by inoculation with potyvirus in resistant cultivar 'Menina'. Unexpectedly, yield in resistant 'Nigerian Local' was reduced an average of $45 \%$ over control plots. Yield loss was $100 \%$ in inoculated plots of susceptible 'Waltham'. Yield reduction ranged from 35\% to $80 \%$ for susceptible Mos166 and moderately resistant 'Soler'. There was little evidence that days to anthesis, average fruit weight, fruit diameter, and fruit quality (mesocarp thickness, chroma, hue angle, ${ }^{\circ}$ Brix and dry matter) of plants inoculated with virus were different from that of uninoculated control plants. The exception was moderately resistant 'Soler' where plants inoculated with ZYMV produced fruits with a $32 \%$ reduction in average weight, as well as reductions in diameter, mesocarp thickness, and color saturation (chroma) compared with controls. This was unexpected given that 'Soler' has some resistance to ZYMV. Greenhouse evaluations by ELISA or symptom severity were generally useful in predicting field resistance to PRSV and ZYMV. In summary, yield reductions of up to $100 \%$ can be expected in $C$. moschata genotypes susceptible to PRSV or ZYMV, but fruit quality traits are usually unaffected. Moderate resistance to ZYMV in 'Soler' was observed to reduced symptom severity but not negative effects on yield and other traits. 'Soler' was not resistant to PRSV. 'Menina' rather than 'Nigerian Local' appears to be the best source of resistance because yield of the former was not impacted by inoculation with either potyvirus.

PRSV and ZYMV are members of the genus Potyvirus and family Potyviridae. Most potyviruses have limited geographical distributions, but PRSV and ZYMV infect cucurbits all around the world (Lecoq et al., 1998). Both viruses are easily transmitted in a nonpersistent manner via aphid feeding. Hosts for PRSV include commercial crops of Caricaceae and Cucurbitaceae (Tripathi et al., 2008), whereas ZYMV is generally limited to the latter. Olarte-Castillo et al. (2011) judged PRSV to be the most important virus disease on cucurbits in the tropics and subtropics. ZYMV was described first in Italy by Lisa et al. (1981); since then, it has been reported in all cucurbit growing areas. Desbiez and Lecoq (1997) list more than 50 locations in Europe, Africa, Asia, Oceana, and North America were ZYMV has been reported.

Viral infections of cucurbit crops were identified in Puerto Rico as early as the 1930s by Cook (1936) and later by Adsuar and Cruz Miret (1950). Surveys in 1981 to 1992 indicated a high incidence of viral diseases around commercial cucurbit farms in Puerto Rico (Escudero, 1992). ZYMV was confirmed in Puerto Rico in 1996 (Lecoq et al., 1998). In 2001 and 2002, a survey of cucurbit crops in Puerto Rico with virus symptoms showed $69 \%$ of all samples infected by ZYMV and $59 \%$ of samples infected with PRSV (Paz-Carrasco and Wessel-Beaver, 2002). Infection with PRSV and ZYMV appeared to lower yields, especially in summer squash (Cucurbita pepo L.) and tropical pumpkin, although no data are given to document this observation.

Tropical pumpkin (C. moschata) is grown worldwide in the lowland (below $3000 \mathrm{~m}$ ) humid tropics. In Puerto Rico, where tropical pumpkin is consumed daily by many people, the crop has consistently been the second most important vegetable crop on the island in economic value (Departamento de Agricultura de Puerto Rico, 2015).

In response to the challenges of susceptibility of $C$. moschata to potyviruses, plant breeders have attempted to identify sources of resistance. Provvidenti et al. (1983), in reference to ZYMV resistance in Cucurbita, mentions that "a few sources of resistance have been found." Munger and Provvidenti (1987) state that the 1983 publication referred to 'Nigerian Local'. According to written correspondence between Provvidenti and L. Wessel-Beaver dated 24 Apr. 2000, seed of the original accession of "Nigerian Local' was obtained from Dr. Igwegbe, University of Nigeria, Nsukka, Anabra State in 1983 (L. Wessel-Beaver, personal communication). Brown et al. (2003) concluded that resistance in 'Nigerian Local' to both PRSV and ZYMV was controlled by a single gene, but later studies found PRSV resistance (McPhail-Medina et al., 2012) and ZYMV resistance (Pachner et al., 2011) in 'Nigerian Local' to be multigenic. Costa (1974) reported the Brazilian genotype 'Menina' to be resistant to PRSV. Paris et al. (1988) also found 'Menina' to be resistant to ZYMV, although it is not clear if this is the same genotype used by Costa (1974) since Paris et al. (1988) reported the genotype to be from Portugal. Pachner et al. (2011) demonstrated that resistance to ZYMV in 'Menina' is conferred by one gene. This same study concluded 
that the Puerto Rican cultivar 'Soler' carries a recessive gene conferring moderate resistance to ZYMV.

Most studies of PRSV and ZYMV mention that these viruses have a negative impact on yield and other traits in cucurbit crops. However, a review of the literature yields few studies that document these impacts, especially in Cucurbita. Demski and Chalkley (1972) reported up to $43 \%$ yield loss in summer squash (C. pepo) inoculated with "watermelon mosaic virus" but it is unclear if this refers to what is now known as PRSV (=WMV-1) or WMV (a separate potyvirus). In New Zealand, Fletcher et al. (2000) inoculated C. maxima 'Delica' with ZYMV at an early stage of growth in the field and observed $48 \%$ yield loss along with a $62 \%$ reduction in number of fruits. Losses were less when inoculations occurred later in the season. Pacheco et al. (2003) observed that biomass was reduced up to $74 \%$ when measured $40 \mathrm{~d}$ after cotyledons of squash $(C$. pepo) were inoculated with a severe strain of PRSV compared with being inoculated with a mild strain of PRSV. 'Menina' (likely the same $C$. moschata cultivar used in our study) did not show any differences when inoculated with severe vs. mild strains of PRSV. They did not continue the study on field-grown plants. Kumar et al. (2008), observed up to a $97 \%$ reduction in yield and $75 \%$ reduction in fruit diameter when working in India with C. moschata inoculated with PRSV.

There are no reports in the literature where the three sources of resistance to PRSV and ZYMV, 'Nigerian Local', 'Menina', and 'Soler' (ZYMV resistance only), have been evaluated together in the field. Nor are there reports on how well greenhouse evaluations for potyvirus resistance are predictive of response in the field. Therefore, our objectives of this research were 1) to compare the development of virus symptoms due to PRSV and ZYMV in susceptible and resistant genotypes of tropical pumpkin from inoculation in the greenhouse to mature plants in the field, 2) to determine whether greenhouse evaluations of PRSV

Received for publication 19 Oct. 2020. Accepted for publication 21 Nov. 2020.

Published online 30 December 2020.

This work was supported by Specialty Crop Research Initiative grant no. 2015-51181-24285 and Hatch accession no. 1000526 from the U.S. Department of Agriculture (USDA) National Institute of Food and Agriculture (NIFA), and the University of Puerto Rico Agricultural Experiment Station. The contents are solely the responsibility of the authors and do not necessarily represent the official views of the USDA or NIFA. This paper is a portion of a thesis submitted by the first author in partial fulfillment of the requirements in a master's degree program.

W.S.-M. is a Former Graduate Student.

L.W.-B. is the corresponding author. E-mail: lindawessel.beaver@upr.edu.

This is an open access article distributed under the CC BY-NC-ND license (https://creativecommons. org/licenses/by-nc-nd/4.0/). and ZYMV are predictive of a genotype's expression of virus infection in the field, and 3 ) to document the effect of PRSV and ZYMV on flowering, yield, and fruit quality of tropical pumpkin.

\section{Materials and Methods}

Preparation of virus inoculum. The Puerto Rico strains of PRSV and ZYMV used in this research (PRSV-PR and ZYMV-PR, respectively) were originally collected from single leaves of single plants of $C$. moschata in a 2008 virus survey in Puerto Rico. ZYMV-PR (GenBank accession number MN422959, Rodrigues Virology Collection No. 161) produced severe disease symptoms when inoculated to various cucurbit species. Both PRSV-PR and ZYMV-PR were multiplied on seedlings of $C$. moschata 'Waltham' [True Leaf Market (previously Mountain Valley Seed Company); Salt Lake City, UT] as described below, and infected tissue was lyophilized and preserved at -20 $\mathrm{C}^{\circ}$ for further use. Trials were conducted using fresh inoculum produced from PRSVor ZYMV-infected dried tissue. To produce fresh inoculum, dried tissue from virusinfected 'Waltham' was macerated in phosphate buffer $(\mathrm{pH} 7)$ added to a cold $\left(-20^{\circ} \mathrm{C}\right)$ mortar in a proportion of $0.12 \mathrm{~g}$ dried tissue to $10 \mathrm{~mL}$ buffer. Using a folded piece of cheesecloth, sap was wiped onto cotyledons of 5-day-old plants previously dusted with silicon carbide (carborundum). After inoculation, cotyledons were lightly rinsed with water to remove carborundum. Plants used as inoculum were kept under artificial light (12-h days) in the laboratory. To avoid cross-contamination, plants of PRSV were kept separate from plants with ZYMV. Approximately $25 \mathrm{~d}$ after inoculation, tissue from the fourth true leaf was sampled to confirm the presence of either PRSV or ZYMV. A commercial kit (Agdia, Elkhart, IN) for a virus-specific (PRSV or ZYMV) DAS-ELISA was used. Tissue samples were assayed in 96-well microplates; readings were made at $405 \mathrm{~nm}$ by a microplate absorbency reader (Multiskan FC 357; Fisher Scientific, Hampton, NH). An unadjusted reading of 0.400 or greater was considered to indicate the presence of virus. Plants with a reading of less than 0.400 were discarded. Each plant was tested for both PRSV and ZYMV. Once confirmed to be infected with a single virus, fresh leaves from a plant could be used as inoculum.

Trial 1 (2016). Six C. moschata genotypes were planted in the greenhouse 11 Mar. 2016 in Mayagüez, PR: 1) 'Menina', seed of which was derived from two generations of selfing of seed provided by T. Lelley, University of Natural Resources and Life Sciences, Vienna, Austria; 2) 'Nigerian Local', seed of which was derived from multiple generations of selfing of seed obtained from R. Provvidenti, Cornell University; 3) 'Soler', a Puerto Rican cultivar with moderate resistance to ZYMV (Pachner et al., 2011) and susceptible to PRSV; 4) 'Taína Dorada', a
Puerto Rican cultivar susceptible to PRSV and ZYMV; 5) Mos166, an experimental line from Puerto Rico, highly susceptible to PRSV and ZYMV; and 6) 'Waltham', a temperate cultivar, highly susceptible to PRSV and ZYMV (Brown et al., 2003). Genotypes were seeded in $10-\mathrm{cm}$ plastic pots filled with Promix BX (Premier Tech, Quakertown, PA). At $5 \mathrm{~d}$, in each of the six genotypes, cotyledons were 1) mockinoculated with buffer (control), 2) inoculated with PRSV, or 3) inoculated with ZYMV. There were 10 plants of each of the six genotypes: four each for inoculation with PRSV and ZYMV, and two used as controls (a total of 60 plants in the trial). Mechanical inoculation was carried out as described previously, using fresh tissue in a proportion of $1.0 \mathrm{~g}$ fresh tissue in $10 \mathrm{~mL}$ of phosphate buffer. At $16 \mathrm{~d}$ post inoculation (DPI), symptom severity was evaluated on the fourth leaf above the cotyledons using a 0 to 5 scale $(0=$ no virus symptoms; 1 = few flecks or lesions, or very mild mottle; 2 = numerous lesions, or strong mosaic or mottle; $3=$ strong mosaic or mottle with some large lesions or blisters; 4 = strong mosaic or mottle with many large lesions or blisters, slight to moderate leaf deformation; $5=$ severe blistering with strong leaf deformation including serrated edges or strapped leaves). At 20 DPI, plants were evaluated for presence of PRSV and ZYMV using the ELISA protocol described previously for inoculum. Each plate contained two buffer and two negative controls. Within a plate, sample readings were adjusted by subtracting the average of the four control readings. Adjusted readings that were less than zero were changed to 0.000 . Control readings varied from $\approx 0.100$ to 0.220 , with standard deviations of 0.050 to 0.063 . The manufacturer of the DAS-ELISA commercial kit used (Agdia, Elkhart, IN) recommends the positive threshold be placed at three times the SD of the control. We rounded up to the nearest tenth of a decimal, and therefore considered adjusted readings of $\geq 0.200$ to be positive for the presence of virus.

On 6 Apr. 2016, plants were transplanted to the field in Lajas, PR, in a completely randomized design into $0.76-\mathrm{m}$-wide raised beds covered in silver plastic mulch (manufacturer unknown, see Fig. 1) over drip lines (5/8-inch, 15 mil, 12-inch Aqua-Traxx; The Toro Company, Bloomington, MN). Plots consisted of single plants spaced $3.7 \mathrm{~m}$ apart within and between rows. To maintain individual plants apart for observation, vines were routinely lifted and trained. A fertilizer solution of $20 \mathrm{~N}-8.8 \mathrm{P}-16.6 \mathrm{~K}$ was applied every 3 weeks via drip irrigation until 126 $\mathrm{kg} \cdot \mathrm{ha}^{-1}$ of N was applied to the crop. Presence of melonworm (Diaphania hyalinata) was monitored and controlled with Bacillus thuringiensis sub. kurstaki (DiPel DF; Valent BioSciences, Libertyville, IL) when necessary. In the field, plants were sampled for an ELISA at 55 DPI. In each plot, samples were collected from two newly expanded leaves. At 28,44 , and 98 DPI, symptom severity was 
rated on the entire plant in each plot using a 0 to 5 scale as previously. Days to anthesis of first staminate and pistillate flower were recorded for each plot.

Trial 2 (2017). The same genotypes as in Trial 1 (2016) were planted in the greenhouse in Mayagüez, PR, 4 Jan. 2017. On 10 Jan. 2017, four inoculation treatments were applied to each genotype: 1) mock-inoculation with buffer (control), 2) inoculation with PRSV, 3) inoculation with ZYMV, and 4) inoculation with PRSV+ZYMV. For plants inoculated with both viruses, one cotyledon was inoculated with PRSV and the other with ZYMV. There were five replications (plants) of each inoculation-genotype combination. At 11 DPI, symptom severity was evaluated as in Trial 1. At $18 \mathrm{DPI}$, greenhouse seedlings were assayed for virus infection by ELISA on the fourth leaf above the cotyledons. As in Trial 1, readings were adjusted and values $\geq 0.200$ were considered to be positive for virus. Seedlings of Mos166, 'Soler', 'Menina', and 'Nigerian Local' were transplanted to the field at Lajas, PR 31 Jan. 2017. Seedlings of 'Taína Dorada' and 'Waltham' were transplanted to the field in Mayagüez, PR, 1 Feb. 2017. Experimental design, plant spacing, and cultural practices were as in Trial 1. In the field, an ELISA was conducted at 54 and 98 DPI. Symptom severity was rated at 40 or 41 DPI in Lajas and Mayagüez, respectively, and at 55 or 72 DPI in Lajas and Mayagüez, respectively. Flowering dates of the first staminate and pistillate flowers were recorded, and fruits were harvested at maturity except for 'Waltham' and 'Taína Dorada'. Number and weight of fruit per plot (per plant), average fruit weight, fruit diameter, and pulp thickness were measured. For pulp color, soluble solids ( ${ }^{\circ}$ Brix) and percentage dry matter, a $2 \mathrm{~cm} \times 5 \mathrm{~cm}$ sample of pulp was cut from each fruit. Fresh weight and pulp color [a* and $\mathrm{b}^{*}$ (coordinates in the color space defined by the International Commission of Illumination) using a Colorflex EZ, HunterLab, Reston, VA] were measured, and the sample was frozen in a plastic bag at $-20{ }^{\circ} \mathrm{C}$. The sample was later thawed, and juice squeezed from the sample was used to measure ${ }^{\circ}$ Brix with a hand-held refractometer (Atago Co., Minato, Tokyo, Japan). The pulp sample was dried in an oven at $65^{\circ} \mathrm{C}$. Hue angle and chroma were calculated from $a^{*}$ and $b^{*}$ using formulas from McGuire (1992). Percentage dry matter was calculated as dry weight divided by the fresh weight and multiplied by 100 .

Statistical analyses. Symptom severity was analyzed separately for each trial (2016 and 2017) as a one-way analysis of variance (ANOVA). Means were separated using a Tukey's test with $\alpha=0.05$. Pearson's correlation was used to determine the linear association between ELISA readings and symptom severity ratings. Flowering from 2016 and 2017, and number of fruits, yield, average fruit weight, fruit diameter, mesocarp (pulp) thickness, chroma, hue angle, ${ }^{\circ}$ Brix, and percentage dry matter data from 2017 were analyzed as one-way ANOVAs.
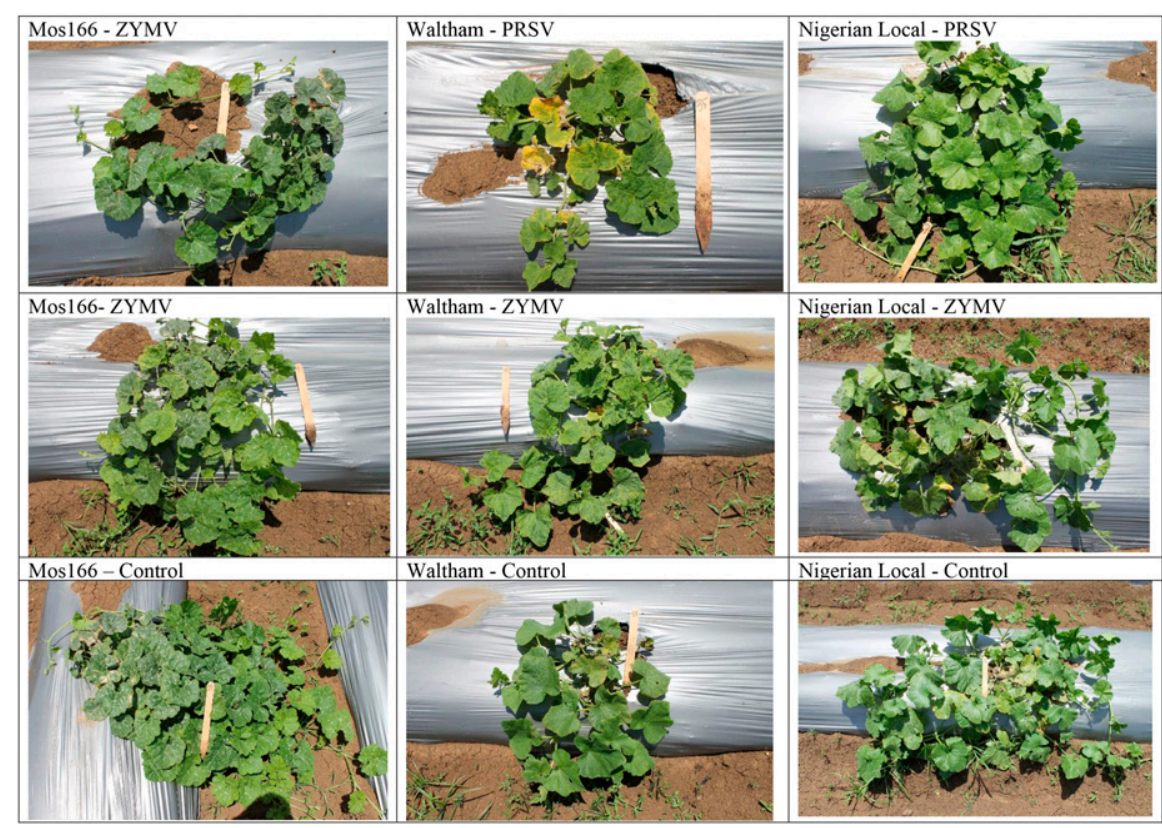

Fig. 1. Susceptible genotypes Mos166 (left) and Waltham (center), and resistant genotype Nigerian Local (right) inoculated with Papaya ringspot virus (PRSV) (top), Zucchini yellow mosaic virus (ZYMV) (center), and mock-inoculated control (bottom) and photographed in Lajas, PR, in 2016 at $44 \mathrm{~d}$ post inoculation.

Within a genotype, single df linear contrasts ( $\alpha=0.05$ ) were used to compare the control (mock-inoculation with buffer) treatment with each inoculation treatment.

\section{Results}

ELISA readings. In both trials (2016 and 2017), control plants in the greenhouse tested negative (ELISA reading $<0.200$ ) for both PRSV and ZYMV (Tables 1 and 2). Susceptible genotypes 'Waltham', Mos166, and 'Taína Dorada' and moderately resistant (for ZYMV) 'Soler' tested positive for PRSV when inoculated with PRSV and positive for ZYMV when inoculated with ZYMV. In the 2017 trial (Table 2), these four genotypes also tested positive for both viruses when inoculated with PRSV+ZYMV (double inoculation). Readings for these genotypes were generally well above the threshold considered positive, especially when inoculated with ZYMV. In 2016, resistant genotypes 'Menina' and 'Nigerian Local' inoculated with PRSV or ZYMV tested negative for the presence of virus (Table 1), whereas in 2017 these same cultivars inoculated with PRSV tested positive for that virus (Table 2). There was no evidence of crosscontamination in the greenhouse in either 2016 or 2017; plants inoculated with PRSV tested negative for ZYMV, and plants inoculated with ZYMV tested negative for PRSV (Tables 1 and 2). When plants were sampled in the field for presence of virus at 55 and 54 DPI (2016 and 2017, respectively), susceptible genotypes continued to test positive for the virus with which they had been inoculated; the readings were again well above the threshold. At this stage, almost all control genotypes had at least some plants testing positive for either PRSV or ZYMV, including 'Menina', which tested positive for PRSV at 55 DPI in 2016. The one exception was 'Nigerian Local', which consistently tested negative for PRSV and ZYMV even up to 98 DPI in 2017 when plants were near full maturity.

Symptom severity. When inoculated with PRSV and ZYMV, visual differences between susceptible genotypes 'Waltham', Mos166, and 'Taína Dorada' and moderately resistant (for ZYMV) 'Soler' vs. resistant genotypes 'Menina' and 'Nigerian Local' were evident in the greenhouse, at the time of transplanting to the field, and through plant maturity. Symptoms were those typically associated with PRSV and ZYMV infection, including leaf deformation (distortion, reduced size, serrated edges) and leaves with mottling, mosaic, lesions (flecks), and/or blistering (Fig. 1). In the greenhouse, controls exhibited no virus symptoms (Tables 3 and 4). Once in the field, some mock-inoculated (control) genotypes became infected and developed low to moderate severity ratings, especially highly susceptible 'Waltham' and Mos166. Overall, average severity ratings never exceeded 2.4 in control plots. PRSV-inoculated seedlings of 'Menina' and 'Nigerian Local' were free of symptoms both in the greenhouse and in the field with the minor exception of a 0.6 severity rating for 'Nigerian Local' at 41 DPI in 2017. These same cultivars inoculated with ZYMV were also free of symptoms except for minor symptoms (severity $=1.00$ ) in 'Nigerian Local' at 98 DPI in 2016. In the greenhouse, susceptible genotypes 'Waltham', Mos166, 
Table 1. Trial 1 (2016): mean enzyme-linked immunosorbent assay (ELISA) readings of six Cucurbita moschata genotypes mock-inoculated (control) and inoculated with Papaya ringspot virus (PRSV) and Zucchini yellow mosaic virus (ZYMV) and sampled in the greenhouse at $20 \mathrm{~d}$ post inoculation (DPI) and in the field at Lajas, PR, at 55 DPI. Readings $\geq 0.2000$ (underlined values) indicate a positive test (presence of the virus).

\begin{tabular}{|c|c|c|c|c|c|}
\hline \multirow[b]{3}{*}{ Inoculation treatment ${ }^{\mathrm{z}}$} & \multirow[b]{3}{*}{ Genotype } & \multicolumn{4}{|c|}{ ELISA reading $^{y}$} \\
\hline & & \multicolumn{2}{|c|}{20 DPI (greenhouse) ${ }^{x}$} & \multicolumn{2}{|c|}{55 DPI (field) ${ }^{x}$} \\
\hline & & PRSV & ZYMV & PRSV & ZYMV \\
\hline Control & Waltham & 0.0225 & 0.0171 & 0.0659 & 0.6399 \\
\hline Control & Mos166 & 0.0003 & 0.0181 & 0.3583 & $\overline{0.0143}$ \\
\hline Control & Taína Dorada & 0.0607 & 0.0270 & $\overline{0.0907}$ & $\underline{0.3811}$ \\
\hline Control & Soler & 0.0045 & 0.0129 & 0.2485 & 0.0782 \\
\hline Control & Menina & 0.0897 & 0.0084 & $\overline{0.4541}$ & 0.0195 \\
\hline Control & Nigerian Local & 0.0968 & 0.0000 & $\overline{0.0368}$ & 0.0096 \\
\hline PRSV & Waltham & 0.5487 & 0.0148 & 1.2237 & 0.0089 \\
\hline PRSV & Mos 166 & $\overline{0.4999}$ & 0.0094 & $\overline{1.2572}$ & 0.0238 \\
\hline PRSV & Taína Dorada & $\overline{0.4584}$ & 0.0124 & $\overline{0.3907}$ & 0.0218 \\
\hline PRSV & Soler & $\overline{0.2289}$ & 0.0047 & $\overline{0.4944}$ & 0.1438 \\
\hline PRSV & Menina & $\overline{0.0796}$ & 0.0128 & $\overline{0.1522}$ & 0.0186 \\
\hline PRSV & Nigerian Local & 0.0673 & 0.0174 & 0.0664 & 0.0158 \\
\hline ZYMV & Waltham & 0.0481 & 0.8579 & 0.1093 & 1.2084 \\
\hline ZYMV & Mos166 & 0.0704 & $\overline{0.8615}$ & 0.1323 & $\overline{1.2753}$ \\
\hline ZYMV & Taína Dorada & 0.0769 & 1.0567 & 0.1053 & $\overline{0.4221}$ \\
\hline ZYMV & Soler & 0.0702 & $\overline{0.5413}$ & 0.1245 & $\overline{0.4025}$ \\
\hline ZYMV & Menina & 0.0894 & $\overline{0.0229}$ & 0.2657 & $\overline{0.0487}$ \\
\hline ZYMV & Nigerian Local & 0.0356 & 0.0133 & $\overline{0.0595}$ & 0.0221 \\
\hline
\end{tabular}

${ }^{\mathrm{z}}$ Genotypes planted in greenhouse in Mayagüez, PR, 11 Mar. 2016. Inoculated 16 Mar. 2016. Transplanted 6 Apr. 2016.

${ }^{\mathrm{y}}$ Adjusted ELISA readings at 405-nm absorbency. Readings were adjusted by averaging the readings of the wells of the negative controls and buffers on a 96 -well plate, then subtracting this value from each sample reading. Negative values were adjusted to 0 .

${ }^{\mathrm{x}}$ In the greenhouse, tissue sampled from the third leaf above cotyledons. In field plots, tissue sampled from two newly expanded leaves on opposite sides of the plant.

Table 2. Trial 2 (2017): mean enzyme-linked immunosorbent assay (ELISA) readings of six Cucurbita moschata genotypes mock-inoculated (control) and inoculated with Papaya ringspot virus (PRSV), Zucchini yellow mosaic virus (ZYMV), and PRSV $+Z \mathrm{YMV}$, and sampled in the greenhouse at $18 \mathrm{~d}$ post inoculation (DPI) and in the field at Lajas, PR, at 54 DPI. Readings $\geq 0.2000$ (underlined values) indicate a positive test (presence of the virus).

\begin{tabular}{|c|c|c|c|c|c|c|c|}
\hline \multirow[b]{3}{*}{ Inoculation treatment ${ }^{\mathrm{z}}$} & \multirow[b]{3}{*}{ Genotype } & \multicolumn{6}{|c|}{ ELISA readings $^{\mathrm{y}}$} \\
\hline & & \multicolumn{2}{|c|}{18 DPI (greenhouse) ${ }^{x}$} & \multicolumn{2}{|c|}{54 DPI (field) ${ }^{x}$} & \multicolumn{2}{|c|}{98 DPI (field) ${ }^{x}$} \\
\hline & & PRSV & $\overline{Z Y M V}$ & PRSV & $\overline{Z Y M V}$ & PRSV & ZYMV \\
\hline Control & Waltham & 0.0186 & 0.1586 & 0.6042 & 0.1686 & - & - \\
\hline Control & Mos166 & 0.0111 & 0.0175 & $\overline{0.0000}$ & 0.0000 & 0.0322 & 0.0052 \\
\hline Control & Taína Dorada & 0.0801 & 0.0208 & $\underline{0.3744}$ & 0.0398 & - & - \\
\hline Control & Soler & 0.0958 & 0.0074 & $\overline{0.0268}$ & 0.0019 & 0.0154 & 0.0034 \\
\hline Control & Menina & 0.0257 & 0.0166 & 0.0000 & 0.0000 & 0.0120 & 0.0030 \\
\hline Control & Nigerian Local & 0.0318 & 0.0075 & 0.0000 & 0.0010 & 0.0068 & 0.0066 \\
\hline PRSV & Waltham & 1.1688 & 0.0348 & 0.5862 & 0.0868 & - & - \\
\hline PRSV & $\operatorname{Mos} 166$ & $\overline{0.8806}$ & 0.0160 & 0.5655 & 0.2779 & 0.5962 & 0.2166 \\
\hline PRSV & Taína Dorada & 0.5829 & 0.0232 & 0.3612 & $\overline{0.0160}$ & - & - \\
\hline PRSV & Soler & 0.3830 & 0.0150 & 0.2517 & 0.0000 & 0.2130 & 0.0000 \\
\hline PRSV & Menina & $\overline{0.2549}$ & 0.0182 & $\overline{0.0518}$ & 0.0040 & $\overline{0.0744}$ & 0.0076 \\
\hline PRSV & Nigerian Local & $\overline{0.4608}$ & 0.0231 & 0.0016 & 0.0000 & 0.0106 & 0.0134 \\
\hline ZYMV & Waltham & $\overline{0.0584}$ & 1.0273 & $\underline{0.2799}$ & $\underline{0.2710}$ & - & - \\
\hline ZYMV & Mos166 & 0.0395 & 0.8053 & 0.0060 & 0.5930 & 0.0393 & 0.7430 \\
\hline ZYMV & Taína Dorada & 0.0696 & 0.6130 & 0.2757 & 0.0750 & - & - \\
\hline ZYMV & Soler & 0.0317 & 0.7660 & 0.0037 & 0.2120 & 0.0254 & 0.3676 \\
\hline ZYMV & Menina & 0.0137 & $\overline{0.0501}$ & 0.0000 & $\overline{0.0000}$ & 0.0080 & $\overline{0.0060}$ \\
\hline ZYMV & Nigerian Local & 0.0097 & 0.0544 & 0.0000 & 0.0744 & 0.0026 & 0.1420 \\
\hline PRSV+ZYMV & Waltham & $\underline{0.4552}$ & $\underline{1.1243}$ & $\underline{0.4701}$ & $\underline{0.4784}$ & - & - \\
\hline PRSV+ZYMV & Mos166 & 0.5196 & 1.6214 & 0.2802 & 0.3829 & 0.4024 & $\underline{0.3510}$ \\
\hline PRSV+ZYMV & Taína Dorada & $\overline{0.4331}$ & 1.3924 & 0.4890 & $\overline{0.1512}$ & - & - \\
\hline PRSV+ZYMV & Soler & 0.4680 & 1.2642 & 0.1773 & 0.4398 & 0.3014 & 0.4420 \\
\hline PRSV+ZYMV & Menina & $\overline{0.1578}$ & $\overline{0.0744}$ & 0.0164 & $\overline{0.0094}$ & $\overline{0.0286}$ & $\overline{0.0260}$ \\
\hline PRSV+ZYMV & Nigerian Local & 0.1027 & 0.0474 & 0.0000 & 0.0000 & 0.0072 & 0.0166 \\
\hline
\end{tabular}

${ }^{\mathrm{z}}$ Genotypes planted in greenhouse in Mayagüez, PR, 4 Jan. 2017. Inoculated 10 Jan. 2017. Transplanted to field 31 Jan. 2017 (Lajas, PR) and 1 Feb. 2017 (Mayagüez, PR).

${ }^{\mathrm{y}}$ Adjusted ELISA readings at 405-nm absorbency. Readings were adjusted by averaging the readings of the wells of the negative controls and buffers on a 96 well plate, then subtracting this value from each sample reading. Negative values were adjusted to 0 .

${ }^{\mathrm{x}}$ In the greenhouse, tissue sampled from the third leaf above cotyledons. In field plots, tissue sampled from two newly expanded leaves on opposite sides of the plant.

- indicates no data.

and 'Taína Dorada' and moderately resistant (for ZYMV) 'Soler' all exhibited moderate to severe symptoms when inoculated with PRSV, ZYMV, or PRSV+ZYMV, with severity ratings ranging from 1.00 to
4.25. Within a susceptible genotype, seedlings inoculated with ZYMV usually had a significantly higher severity rating compared with seedlings inoculated with PRSV. This general trend continued when severity ratings were done in the field, although the differences were not always significant. In the greenhouse, susceptible genotypes subjected to double inoculation of PRSV+ZYMV (2017 trial) often 
Table 3. Trial 1 (2016): average virus symptom severity ratings of six Cucurbita moschata genotypes mock-inoculated (control), inoculated with Papaya ringspot virus (PRSV), and inoculated with Zucchini yellow mosaic virus (ZYMV) at the cotyledon stage. Symptom severity rated in the greenhouse at $16 \mathrm{~d}$ post inoculation (DPI), and in the field at Lajas, PR, at 28, 44, and 98 DPI.

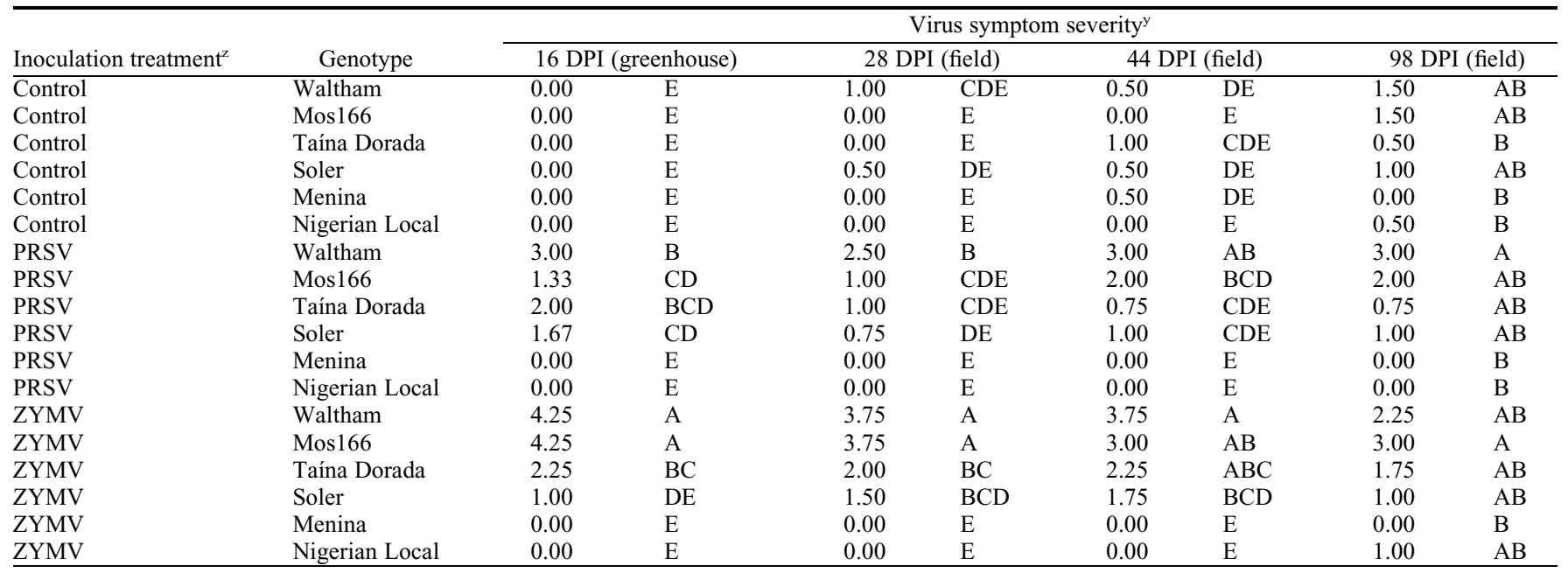

${ }^{\mathrm{z}}$ Genotypes seeded in greenhouse in Mayagüez, PR, 11 Mar. 2016. Inoculated 16 Mar. 2016. Transplanted 6 Apr. 2016.

${ }^{\mathrm{y}}$ In greenhouse, symptom severity evaluated on the fourth leaf above cotyledons using a 0 to 5 scale $(0=$ no virus symptoms; $1=$ few flecks or lesions, or very mild mottle; 2 = numerous lesions, or strong mosaic or mottle; 3 = strong mosaic or mottle with some large lesions or blisters; $4=$ strong mosaic or mottle with many large lesions or blisters, slight to moderate leaf deformation; $5=$ severe blistering with strong leaf deformation including serrated edges or strapped leaves). In the field, symptom severity evaluated on a whole-plant basis on a 0 to 5 scale as previously, considering symptoms in entire plant.

Within a column, means followed by a common letter are not significantly different at the $0.05 P$ level according to Tukey's test.

Table 4. Trial 2 (2017): average virus symptom severity ratings of six Cucurbita moschata genotypes mock-inoculated (control), inoculated with Papaya ringspot virus (PRSV), inoculated with Zucchini yellow mosaic virus (ZYMV), and inoculated with PRSV+ZYMV at the cotyledon stage. Symptom severity was rated in the greenhouse $11 \mathrm{~d}$ post inoculation (DPI), and in the field at 41 and 55 DPI at Lajas, PR (Mos166, Soler, Menina, and Nigerian Local), or 40 and 72 DPI at Mayagüez, PR (Waltham and Taína Dorada).

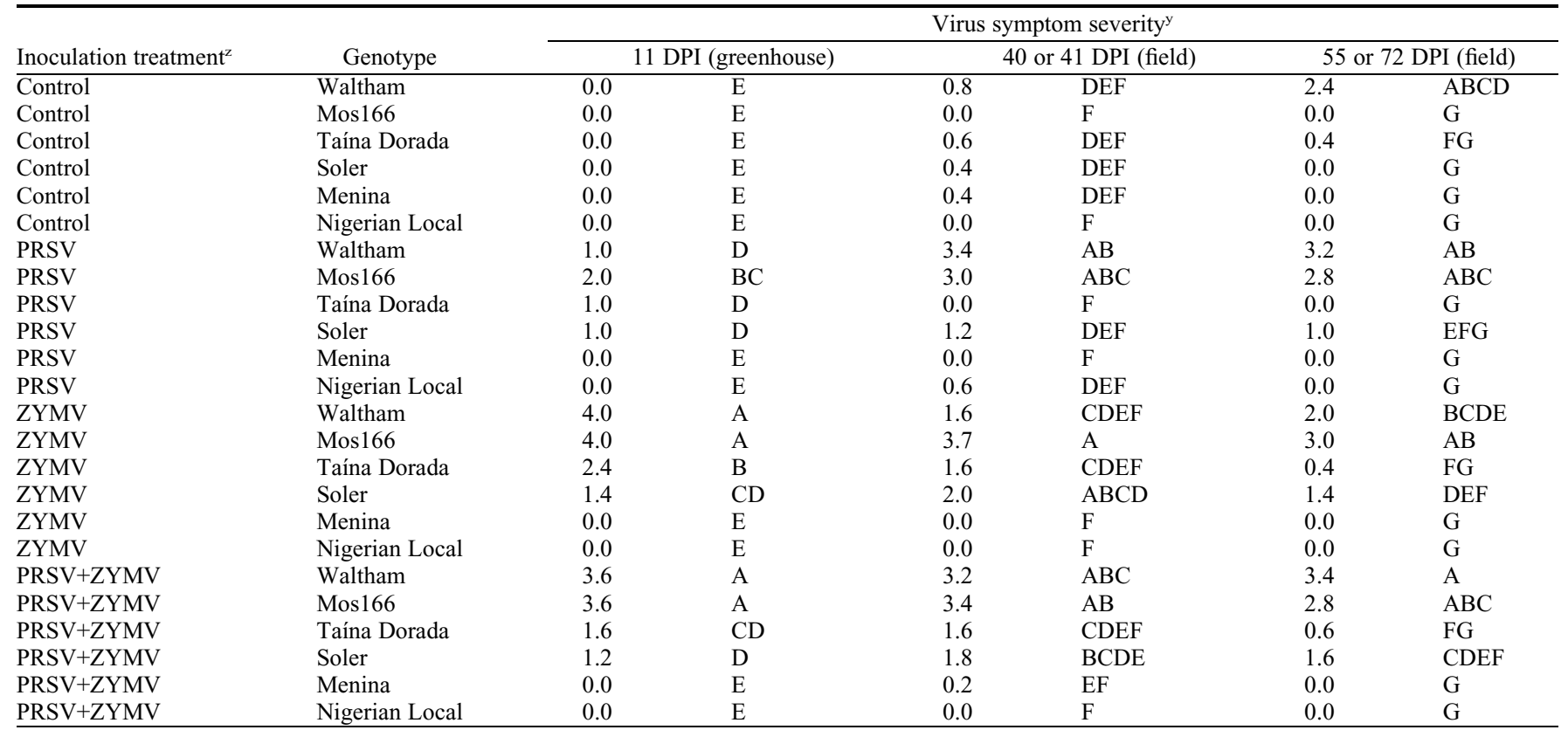

${ }^{\mathrm{z}}$ Genotypes seeded in greenhouse in Mayagüez, PR, 4 Jan. 2017. Inoculated 10 Jan. 2017. Transplanted to field 31 Jan. 2017 (Lajas, PR) and Feb. 2017 (Mayagüez, PR).

${ }^{\mathrm{y}}$ In greenhouse, symptom severity evaluated on the second leaf above cotyledons using a 0 to 5 scale $(0=$ no virus symptoms; $1=$ few flecks or lesions, or very mild mottle; 2 = numerous lesions, or strong mosaic or mottle; $3=$ strong mosaic or mottle with some large lesions or blisters; $4=$ strong mosaic or mottle with many large lesions or blisters, slight to moderate leaf deformation; $5=$ severe blistering with strong leaf deformation including serrated edges or strapped leaves). In the field, symptom severity evaluated on a whole-plant basis on a 0 to 5 scale as previously, considering symptoms in entire plant.

Within a column, means followed by a common letter are not significantly different at the $0.05 P$ level according to Tukey's test.

exhibited more severe symptoms than with PRSV inoculation alone, but less severe symptoms than with ZYMV alone (Table 4). However, this trend did not continue when comparing symptom severity in the field.
Association between ELISA readings and symptom severity ratings in the greenhouse and the field. Correlations between and among ELISA readings and symptom severity ratings were always positive and significant $(P<0.001)$, ranging from 0.37 to 0.75
(Figs. 2 to 7). Correlations between field vs. greenhouse ELISA readings were poor $(r=$ 0.37 ) for PRSV but moderate for ZYMV ( $r=$ 0.52 ). For severity ratings, correlations between the greenhouse and field were moderate $(r=0.56)$ for PRSV and strong $(r=0.75)$ 


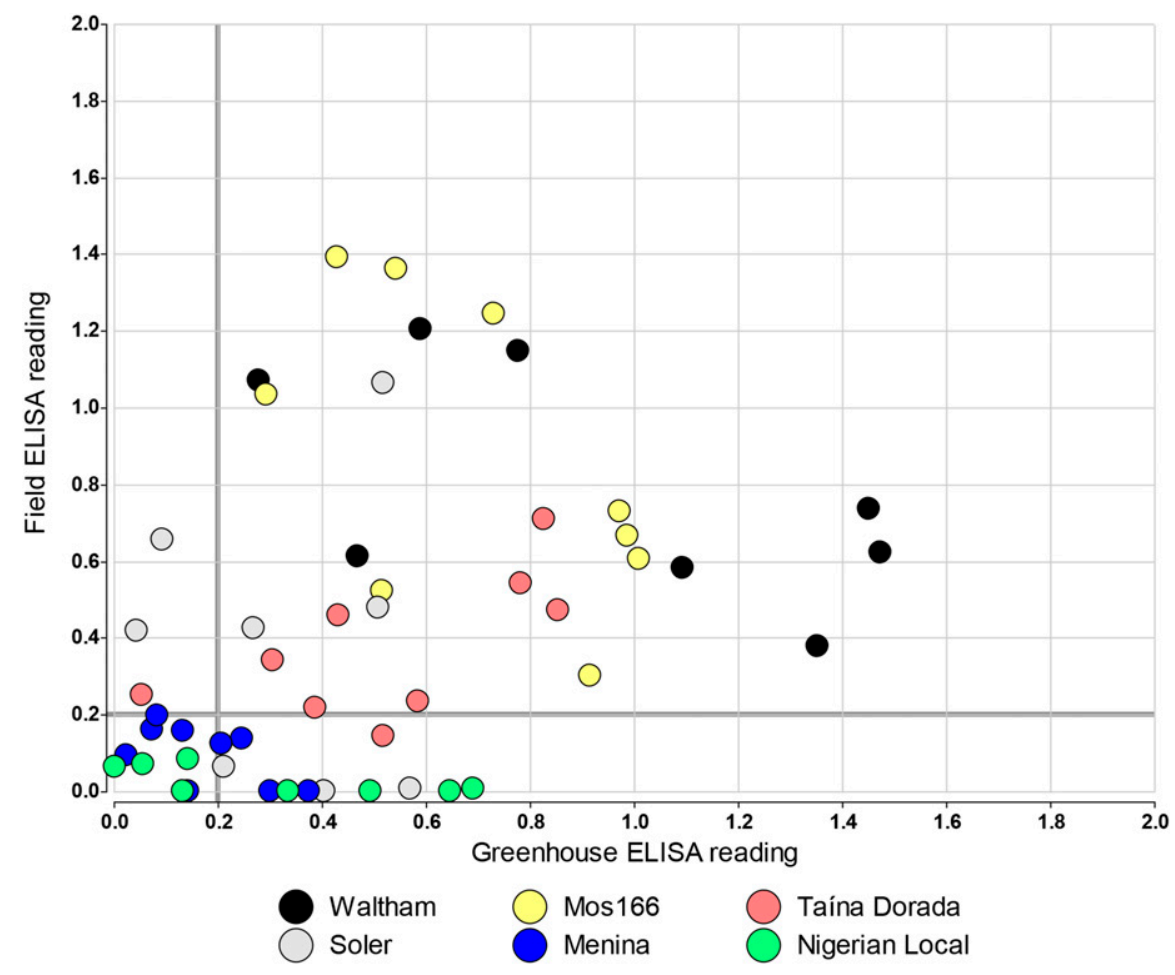

Fig. 2. Enzyme-linked immunosorbent assay (ELISA) readings $(405 \mathrm{~nm})$ in the greenhouse vs. the field in individual plants of six Cucurbita moschata genotypes inoculated at the cotyledon stage with Papaya ringspot virus (PRSV). Data from 2016 and 2017 are combined in the graph. Greenhouse readings were taken at $20 \mathrm{~d}$ post inoculation (DPI) in 2016 and at 18 DPI in 2017. Field readings were taken at 44 DPI in 2016 and at 41 to 42 DPI in 2017. ELISA readings $\leq 0.20$ (vertical and horizontal lines) are considered to be negative for the presence of PRSV. $r=$ Pearson's correlation coefficient. Some data points in the graph are covered by other points with a similar or equal reading.

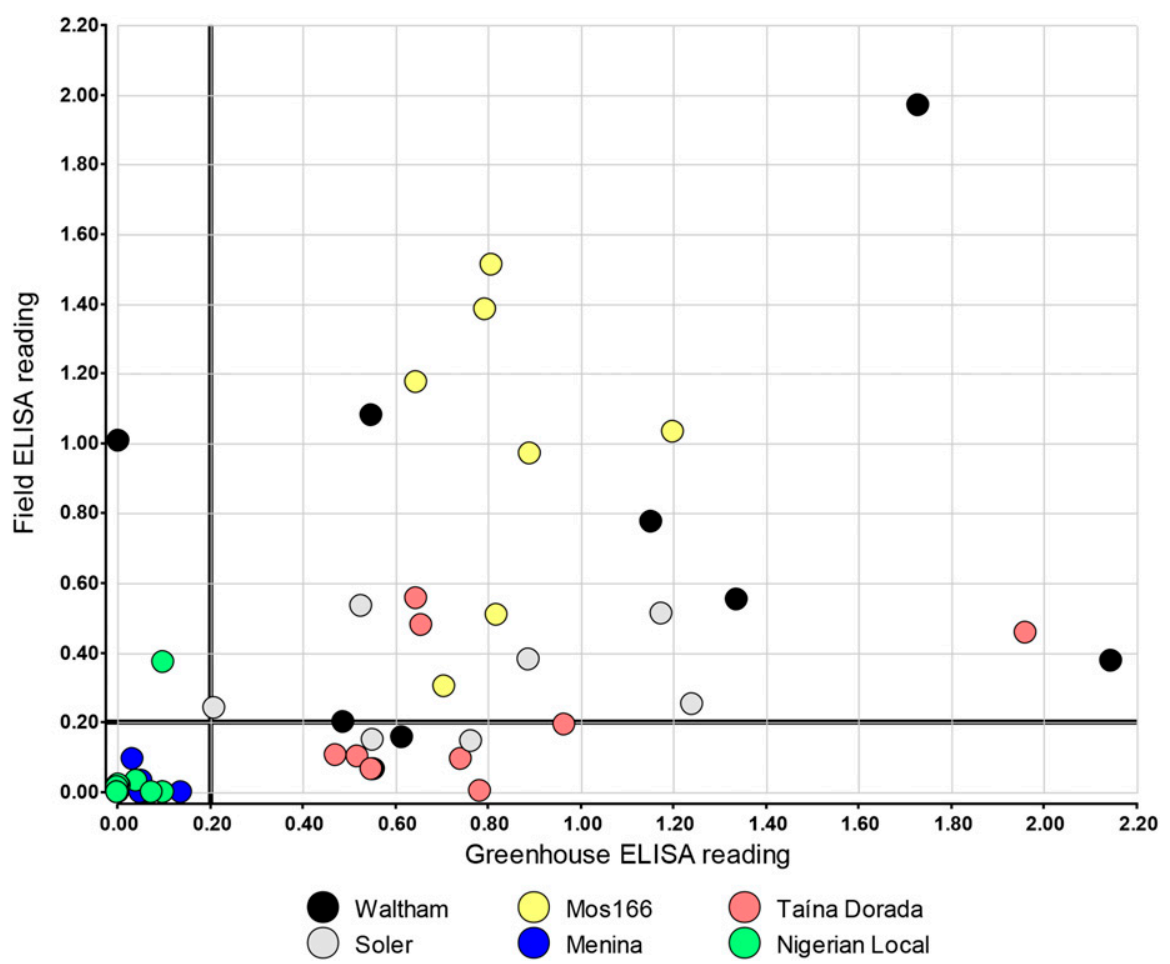

Fig. 3. Enzyme-linked immunosorbent assay (ELISA) readings $(405 \mathrm{~nm})$ in the greenhouse vs. the field in individual plants of six Cucurbita moschata genotypes inoculated at the cotyledon stage with Zucchini yellow mosaic virus (ZYMV). Data from 2016 and 2017 are combined in the graph. Greenhouse readings were taken at $20 \mathrm{~d}$ post inoculation (DPI) in 2016 and at 18 DPI in 2017. Field readings were taken at 44 DPI in 2016 and at 41 to 42 DPI in 2017. ELISA readings $\leq 0.20$ (vertical and horizontal lines) are considered to be negative for the presence of ZYMV. $r$ = Pearson's correlation coefficient. Some data points in the graph are covered by other points with a similar or equal reading. for ZYMV. In the greenhouse, correlations between ELISA and severity were poor for PRSV $(r=0.37)$ and moderate for ZYMV $(r=0.67)$. For both PRSV and ZYMV, 'Nigerian Local' and 'Menina' were almost always classified as negative for the presence of virus according to ELISA and resistant according to severity. The exception was for PRSV, where greenhouse ELISA readings of these two genotypes sometimes fell in the range of $>0.200$ in the greenhouse while being $<0.200$ in the field (Fig. 2). For the other four genotypes, the association between greenhouse and field evaluations or between ELISA readings and severity ratings was less consistent. Nevertheless, for ELISA and for severity, most plants of susceptible genotypes fell into the upper right quadrant in Figs. 2 to 7 , indicating a classification of "susceptible" in both the greenhouse and field.

Effect of PRSV and ZYMV on flowering, yield, and fruit quality. Compared with the uninoculated control, yield per plant was unaffected by inoculation with potyvirus in resistant cultivar Menina $(P=0.7369$ to 0.9431 ) (Table 5). Yield in resistant 'Nigerian Local' was reduced an average of $45 \%$ over uninoculated plots $(P=0.013$ to 0.0013). Control plots of 'Waltham' were so severely affected by virus contamination (severity $=2.4$, Table 4 ) that no formal comparison was made between control and inoculated plots. No marketable fruits were harvested from any plots (100\% yield loss). In susceptible Mos166, yield was reduced by an average of $80 \%$ in plants inoculated with potyvirus $(P=0.0004$ to $<0.0001)$. Yield in moderately susceptible 'Soler' inoculated with ZYMV was reduced by $35 \%(P=$ $0.0395)$, and there was some evidence ( $P=$ 0.0959 to 0.1629 ) that yields were also reduced in plants inoculated with PRSV and PRSV+ZYMV by a similar magnitude. In contrast to yield, the effect of virus inoculation on other traits was far less. Some genotypes exhibited delayed flowering of both male and female flowers when inoculated with potyvirus, but the effect varied depending on genotype and virus (Table 5). There was no effect of virus inoculation on flowering in the 2016 trial (data not shown). In three of the four genotypes, there was little or no evidence $(P>$ 0.05 ) that average fruit weight, fruit diameter, and fruit quality (mesocarp thickness, chroma, hue angle, brix, and dry matter) of plants inoculated with virus were different from that of uninoculated control plants (Tables 5 and 6). The exception was 'Soler' where plants inoculated with ZYMV produced fruits with a $32 \%$ reduction in average weight, a $13 \%$ reduction in diameter, a $13 \%$ reduction in mesocarp thickness, and a $15 \%$ reduction in color saturation (chroma) compared with uninoculated plants ( $P=0.0098$ to 0.0330 ).

\section{Discussion}

The effectiveness of mechanical inoculation for both PRSV and ZYMV was confirmed by greenhouse ELISA readings that were positive for the presence of virus in susceptible genotypes 'Waltham', Mos166, 


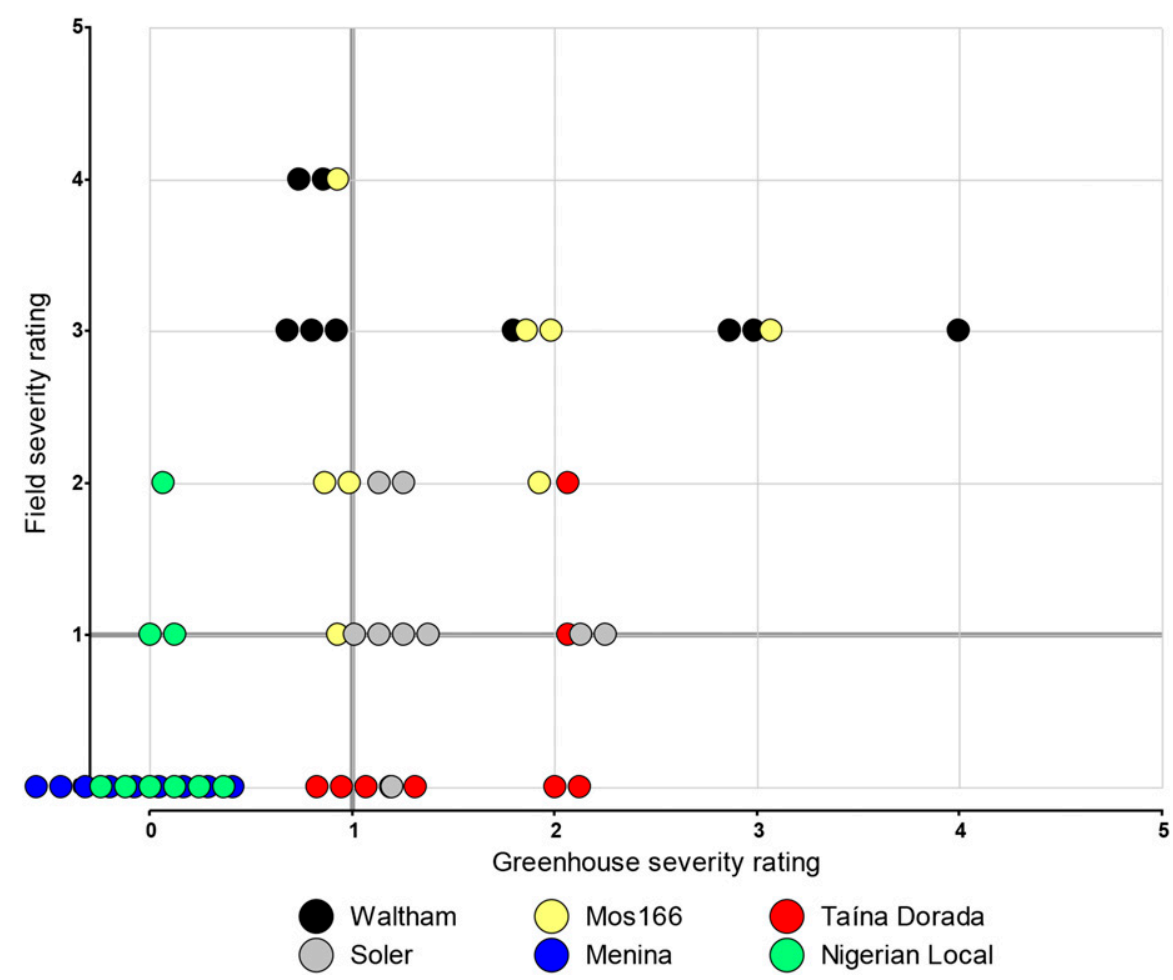

Fig. 4. Symptom severity ratings (1 to 5 scale) in the greenhouse vs. field in individual plants of six Cucurbita moschata genotypes inoculated at the cotyledon stage with Papaya ringspot virus (PRSV). Data from 2016 and 2017 are combined in the graph. Greenhouse severity ratings were taken at 16 DPI on the fourth leaf in 2016 and 11 DPI on the second leaf in 2017. Field severity ratings were taken at 44 DPI in 2016 and 41 to 42 DPI in 2017. Plants with a severity rating $\leq 1$ are considered resistant to PRSV. $r=$ Pearson's correlation coefficient. To show all data, points aligned horizontally around a particular severity rating have the same rating.

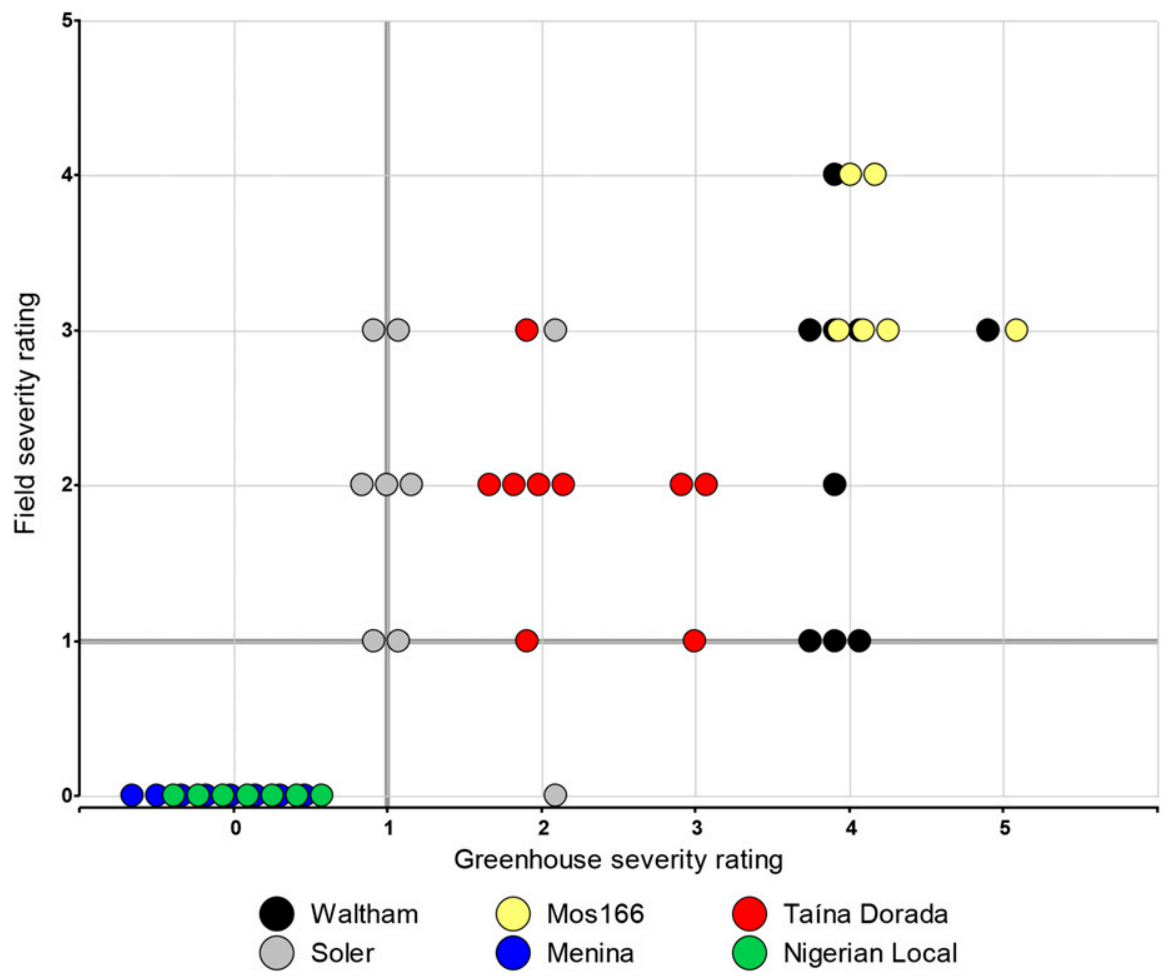

Fig. 5. Symptom severity ratings (1 to 5 scale) in the greenhouse vs. field in individual plants of six Cucurbita moschata genotypes inoculated at the cotyledon stage with Zucchini yellow mosaic virus (ZYMV). Data from 2016 and 2017 are combined in the graph. Greenhouse symptom severity ratings were taken at 16 DPI on the fourth leaf in 2016 and 11 DPI on the second leaf in 2017. Field symptom severity ratings on the entire plant were taken at 44 DPI in 2016 and 41 to 42 DPI in 2017. Plants with a symptom severity rating $\leq 1$ are considered resistant to ZYMV. $r$ = Pearson's correlation coefficient. Some data points in the graph are covered by other points with a similar or equal reading. and 'Taína Dorada', and moderately resistant (for ZYMV) 'Soler' (Tables 1 and 2). Negative readings confirmed the absence of virus in control plants. Although all controls were negative for presence of virus in the greenhouse, positive ELISA readings among some control plants in the field indicated that contamination occurred after transplanting. Those readings were generally lower than that of inoculated susceptible genotypes. Aphid vectors are continuously present in the field in Puerto Rico. In 2016, inoculated plants of resistant 'Menina' and 'Nigerian Local' tested negative for both viruses in the greenhouse and field (Table 1). In 2017, these genotypes tested positive for PRSV in the greenhouse but were later negative in the field (Table 2). Previous unpublished data from authors WS-M and LW-B suggest that positive ELISA readings in resistant 'Menina' and 'Nigerian Local' can occur when plants are tested early. ELISA was done 20 DPI in 2016 and 18 DPI in 2017.

'Waltham' is adapted to temperate zones but was included with tropical pumpkin genotypes in this study because it has been used as a susceptible parent in inheritance studies for both PRSV (Brown et al., 2003; McPhailMedina et al., 2012) and ZYMV (Brown et al., 2003; Munger and Provvidenti, 1987; Pachner et al., 2011; Paris et al., 1988). Mos166 is an experimental tropical pumpkin line derived from an introduction from Central America. It was previously observed to be highly susceptible in the greenhouse in unpublished work by the authors. 'Taína Dorada', a cultivar developed at the University of Puerto Rico, was previously observed to be susceptible in the greenhouse to PRSV, although somewhat less so than 'Waltham' (McPhail-Medina et al., 2012). Based on symptom severity (Tables 3 and 4), our study confirmed PRSV and ZYMV susceptibility of these three genotypes in the greenhouse. In addition, we document their susceptibility to these viruses in the field.

'Soler' was also developed at the University of Puerto Rico. In a greenhouse study, Pachner et al. (2011) described 'Soler' as carrying a recessive gene for moderate resistance to ZYMV. Our study confirmed this moderate resistance in the greenhouse and, to a lesser extent, in the field. In plots inoculated with ZYMV, 'Soler' generally had less severe symptoms than the susceptible genotypes 'Waltham', Mos166, and 'Taína Dorada'. When 'Soler' was inoculated with PRSV, symptom severity was generally not different from that of the susceptible genotypes (Tables 3 and 4).

'Menina' and 'Nigerian Local' exhibited no symptoms in the greenhouse and field (Tables 3 and 4). There is some confusion about the origin of 'Menina'. Our seed stock of 'Menina' was derived, via self-pollination, from seed provided by T. Lelley, coauthor of Pachner et al. (2011). Pachner et al. (2011) obtained their seed of 'Menina' from M. Pitrat, I.N.R.A., France. Paris et al. (1988) used 'Menina' as a resistant parent in a study of inheritance of ZYMV. Their paper states 


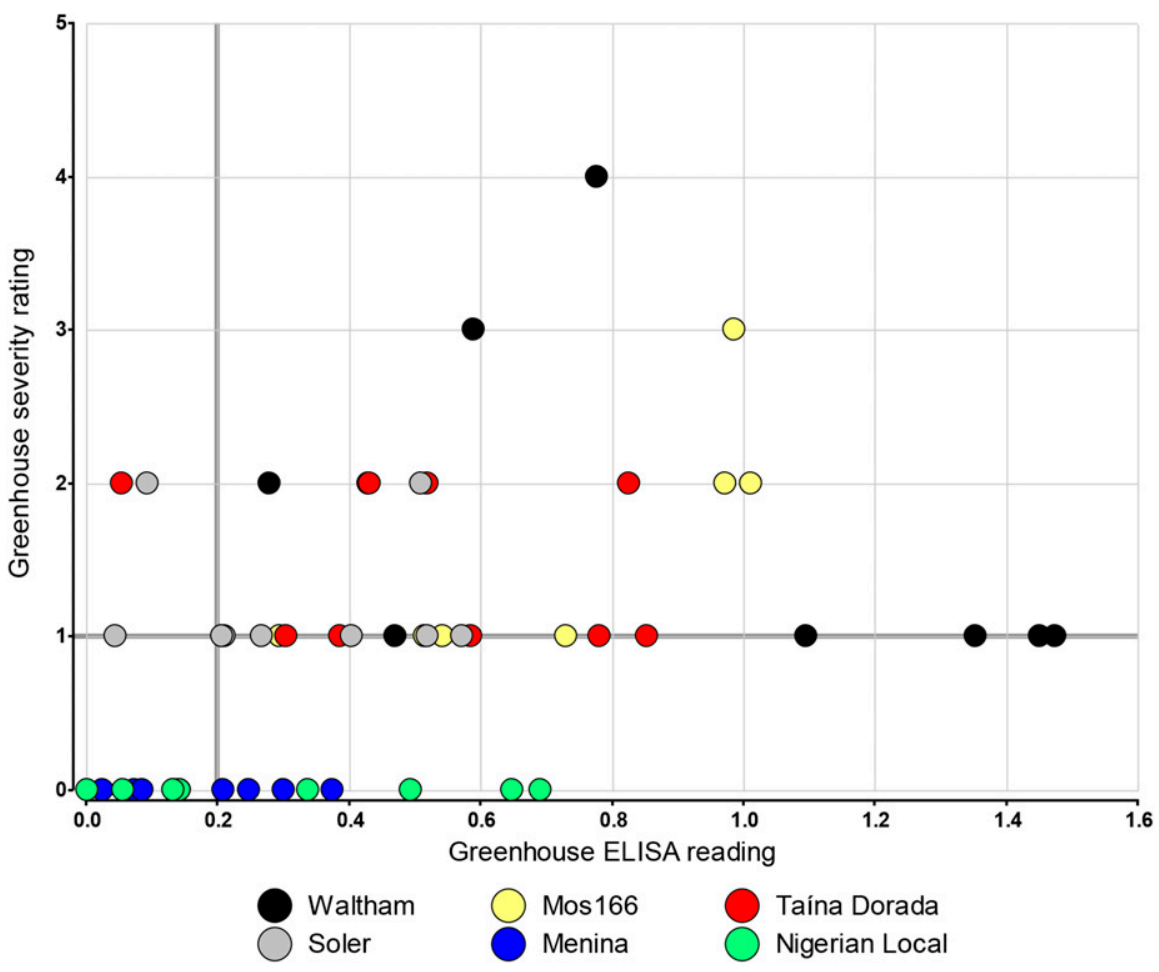

Fig. 6. Enzyme-linked immunosorbent assay (ELISA) readings $(405 \mathrm{~nm})$ in the greenhouse vs. symptom severity ratings ( 1 to 5 scale) in the greenhouse in individual plants of six Cucurbita moschata genotypes inoculated at the cotyledon stage with Papaya ringspot virus (PRSV). Data from 2016 and 2017 are combined in the graph. Greenhouse ELISA readings were taken at $20 \mathrm{~d}$ post inoculation (DPI) in 2016 and at 18 DPI in 2017. Greenhouse symptom severity ratings were taken at 16 DPI on the fourth leaf in 2016 and 11 DPI on the second leaf in 2017. ELISA readings $\leq 0.20$ (vertical and horizontal lines) are considered to be negative for the presence of PRSV. Plants with a symptom severity rating $\leq 1$ are considered resistant to PRSV. $r=$ Pearson's correlation coefficient. Some data points in the graph are covered by other points with a similar or equal reading.

that "Seed samples of 'Menina' were obtained from Portugal" and describes the cultivar as "Portuguese." Paris and Cohen (2000), who used 'Menina' to transfer ZYMV resistance to $C$. pepo, commented that the seed stock in Paris et al. (1988) contained both susceptible and resistant individuals. Going back earlier to work in Brazil, Maluf et al. (1986) found 'Menina Brasiliera' to be resistant to PRSV. Rezende et al. (1999) described 'Menina Brasiliera' as being somewhat tolerant to PRSV, whereas Nascimento et al. (2012) found 'Menina Brasiliera' to be susceptible to PRSV. The color photograph of fruits of 'Menina Brasiliera' in Rezende et al. (1999) have much longer and thinner necks than fruits of 'Menina' in our study, although in general, fruit type is similar. Given the cultural connections between Portugal and Brazil, it seems likely that 'Menina' in our study was derived, via some degree of selection for ZYMV resistance, from 'Menina Brasiliera', either in Brazil or Portugal. This seed stock found its way to Paris et al. (1988) and Paris and Cohen (2000) in Israel, who likely shared it with Pitrat in France, who then shared it with Pachner et al. (2011) who, working in Austria, clearly established that 'Menina' is resistant to ZYMV. Our current study con- survey conducted in Puerto Rico, 62\% of samples were found to be infected with more than one virus and the combination of PRSV and ZYMV was particularly common (PazCarrasco and Wessel-Beaver, 2002).

When there is a strong association between greenhouse and field-based evaluations for virus resistance, then selection can be carried out with confidence in the greenhouse. Greenhouse evaluations take far less space and can be carried out far earlier than field evaluations. Although many breeders use greenhouse screening to select for virus resistance, we know of no previously published studies comparing greenhouse vs. field phenotyping for resistance to PRSV and ZYMV in tropical pumpkin. Wessel-Beaver and Rodrigues (2016) determined that, for ELISA, sampling the fourth leaf above the cotyledons is effective for distinguishing PRSV and ZYMV resistance between genotypes of tropical pumpkin. In our study, we used that leaf for ELISA tests. Severity was rated on the fourth leaf in 2016 and on the second leaf in 2017. All correlations between ELISA readings and severity ratings were positive. In 2016 there were some strong correlations between greenhouse and field severity ratings, but these were not repeated in 2017 (data not shown). Ratings on the second leaf, rather than the fourth, may explain the lower correlations in 2017. Especially for PRSV, clear symptoms tend to develop on the third or later leaves. Correlations measure linear associations and therefore may not be completely indicative of the association between greenhouse and field measurements. In the scattergrams (Figs. 2 to 5), plants that fell in the upper right quadrant are those that were classified "susceptible" in both the greenhouse and field. Likewise, plants that fell in the lower left quadrant are those that were classified "resistant" in both the greenhouse and the field. Because most plants fell in one of those two quadrants, we can conclude that greenhouse evaluations are generally predictive of field performance. Perhaps of greatest concern are plants that fall into the lower-right quadrant. These are "false positives" in the greenhouse. Eliminating such plants in the greenhouse would eliminate a genotype with good field resistance. For both PRSV and ZYMV, severity ratings had stronger correlations between the greenhouse and field. The use of severity ratings has the advantage of being fast and low cost compared with ELISA.

Other than for yield, our study found less effect of PRSV and ZYMV on tropical pumpkin than expected, especially given that plants were inoculated in the cotyledon stage and clear symptoms of virus infection were observed both in the greenhouse and in the field. All inoculated seedlings transplanted to the field were individually confirmed to be infected via ELISA (Tables 1 and 2) and showed symptoms (Tables 3 and 4). Positive ELISA readings and severity ratings continued to confirm infection in the field. The temperate cultivar 'Waltham' was so severely affected by virus that no fruit were 
harvested. But only yield, and to a lesser fruit size and diameter, showed marked negative effects of virus infection in tropical pumpkin genotypes (Tables 5 and 6). Except for 'Waltham', which had very distorted fruit marked with ringspots, blisters, and other lesions, we observed only minimal ringspots and lesions on the rinds of fruits of other susceptible genotypes. We were surprised that yields and fruit diameter were reduced in 'Soler' infected with ZYMV given that this cultivar has a gene for moderate resistance (Pachner et al., 2011) and was observed to have lower severity ratings than other susceptible genotypes (Tables 3 and 4). Even more surprising was that yields of 'Nigerian Local' were negatively affected by both viruses when no foliage symptoms were ob-

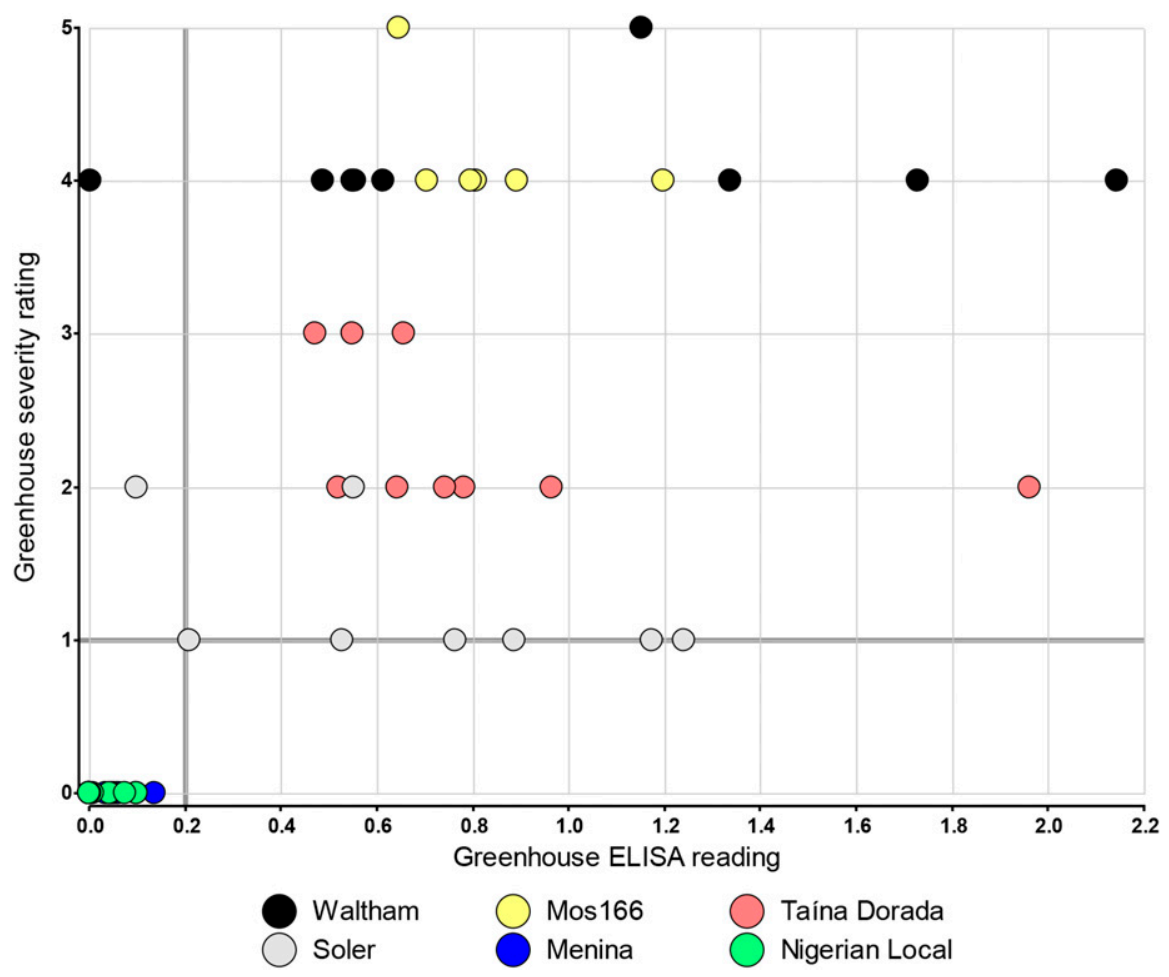

Fig. 7. Enzyme-linked immunosorbent assay (ELISA) readings $(405 \mathrm{~nm})$ in the greenhouse vs. symptom severity ratings (1 to 5 scale) in the greenhouse in individual plants of six Cucurbita moschata genotypes inoculated at the cotyledon stage with Zucchini yellow mosaic virus (ZYMV). Data from 2016 and 2017 are combined in the graph. Greenhouse ELISA readings were taken at $20 \mathrm{~d}$ post inoculation (DPI) in 2016 and at 18 DPI in 2017. Greenhouse symptom severity ratings were taken at 16 DPI on the fourth leaf in 2016 and 11 DPI on the second leaf in 2017. ELISA readings $\leq 0.20$ (vertical and horizontal lines) are considered to be negative for the presence of ZYMV. Plants with a symptom severity rating $\leq 1$ are considered resistant to ZYMV. $r=$ Pearson's correlation coefficient. Some data points in the graph are covered by other points with a similar or equal reading. served in the greenhouse or field. We do note, however, that the initial ELISA reading at 18 DPI was positive for the presence of PRSV in plants inoculated with PRSV. ELISA readings in the field were negative for PRSV. The negative ELISA readings for 'Nigerian Local' (Tables 1 and 2) suggest that 'Nigerian Local' carried little if any virus. This contrasts with what has been observed with the resistant C. pepo cv. Whitaker. 'Whitaker' derives its PRSV and ZYMV resistance from Cucurbita ecuadorensis and has been widely used as a parent in the seed industry. Most, if not all, cultivars derived from 'Whitaker' have suppressed symptoms, but are asymptomatic carriers, meaning they can infect other susceptible plants (Michael Mazourek, personal communication). Miranda-Vélez et al. (2019) demonstrated that 'Nigerian Local' and 'Menina' are not asymptomatic carriers of PRSV and ZYMV.

Within a genotype, inoculated plots were compared with controls. Once plants were moved to the field, they were no longer protected from possible cross-contamination via insect vectors present in the field. Inoculated plants in the experiment itself, as well as ever-present wild cucurbit species on the island could have provided a source of inoculum (Rodrigues et al., 2012). The presence of infected control plants would have reduced the differences between control and inoculated plots. However, except for 'Waltham', control plots in the field had only minimal virus symptoms (Table 4).

\section{Conclusion}

Genotypes 'Menina' and 'Nigerian Local' exhibited few or no foliar symptoms in the greenhouse or field when inoculated with PRSV, ZYMV, or PRSV+ZYMV. ELISA readings in both the greenhouse and field were also consistently negative for virus. Severity ratings for 'Soler' inoculated with ZYMV were somewhat lower than for the susceptible genotypes, confirming a previous greenhouse study identifying a recessive

Table 5. Trial 2 (2017): means of flowering, number of fruits per plant, yield and fruit weight in four genotypes of tropical pumpkin Cucurbita moschata uninoculated and inoculated with Papaya ringspot virus (PRSV), Zucchini yellow mosaic virus (ZYMV) or both viruses (PRSV $+\mathrm{ZYMV),} \mathrm{and} \mathrm{transplanted} \mathrm{to}$ the field in Lajas, PR. Within a genotype, a single df linear contrast compares the uninoculated control with each inoculation treatment $(P$ value).

\begin{tabular}{|c|c|c|c|c|c|c|c|c|c|c|c|}
\hline Genotype & $\begin{array}{c}\text { Inoculation } \\
\text { treatment }\end{array}$ & \multicolumn{4}{|c|}{ Days from transplant to flowering } & $\begin{array}{c}\text { No. of } \\
\text { fruit per plant }\end{array}$ & $P$ value & $\begin{array}{l}\text { Yield per } \\
\text { plant }(\mathrm{kg})\end{array}$ & $P$ value & $\begin{array}{l}\text { Avg fruit } \\
\text { wt (kg) }\end{array}$ & $P$ value \\
\hline \multirow{2}{*}{ Mos166 } & Uninoculated & 32.3 & & 33.4 & & 7.0 & & 8.17 & & 1.17 & \\
\hline & PRSV+ZYMV & 40.8 & 0.0769 & 47.0 & 0.0112 & 5.2 & 0.0747 & 1.61 & 0.0001 & 0.31 & 0.3524 \\
\hline \multirow[t]{2}{*}{ Soler } & Uninoculated & 40.0 & & 52.0 & & 1.0 & & 9.57 & & 8.20 & \\
\hline & PRSV & 38.4 & 0.7059 & 52.6 & 0.9083 & 0.4 & 0.5477 & 6.73 & 0.1629 & 6.73 & 0.2436 \\
\hline \multirow[t]{4}{*}{ Menina } & Uninoculated & 20.4 & & 47.4 & & 0.8 & & 3.00 & & 3.00 & \\
\hline & PRSV & 37.6 & 0.0001 & 44.3 & 0.6107 & 1.0 & 0.8410 & 3.13 & 0.9431 & 2.04 & 0.3848 \\
\hline & ZYMV & 27.2 & 0.1126 & 49.6 & 0.6731 & 1.2 & 0.6883 & 2.48 & 0.7369 & 2.02 & 0.3123 \\
\hline & PRSV+ZYMV & 29.6 & 0.0334 & 51.5 & 0.4593 & 0.6 & 0.8410 & 2.55 & 0.8212 & 1.70 & 0.2407 \\
\hline \multirow[t]{3}{*}{ Nigerian Local } & Uninoculated & 23.4 & & 42.4 & & 4.8 & & 10.28 & & 2.14 & \\
\hline & PRSV & 24.3 & 0.8500 & 44.8 & 0.6709 & 4.4 & 0.6883 & 6.27 & 0.0130 & 1.12 & 0.2933 \\
\hline & ZYMV & 21.7 & 0.7233 & 55.3 & 0.0351 & 2.3 & 0.0184 & 5.57 & 0.0078 & 1.94 & 0.8452 \\
\hline
\end{tabular}


Table 6. Trial 2 (2017): Means of fruit diameter and mesocarp thickness, chroma, hue angle, brix, and dry matter in four genotypes of tropical pumpkin Cucurbita moschata uninoculated and inoculated with Papaya ringspot virus (PRSV), Zucchini yellow mosaic virus (ZYMV) or both viruses (PRSV+ZYMV), and transplanted to the field in Lajas, PR. Within a genotype, a single df linear contrast compares the uninoculated control with each inoculation treatment $(P$ value).

\begin{tabular}{|c|c|c|c|c|c|c|c|c|c|c|c|c|c|}
\hline Genotype & $\begin{array}{c}\text { Inoculation } \\
\text { treatment }\end{array}$ & $\begin{array}{l}\text { Fruit diam } \\
\qquad(\mathrm{cm})\end{array}$ & $P$ value & $\begin{array}{c}\text { Mesocarp } \\
\text { thickness }(\mathrm{cm})\end{array}$ & $P$ value & Chroma & $P$ value & $\begin{array}{c}\text { Hue } \\
\text { angle }\left({ }^{\circ}\right)\end{array}$ & $P$ value & ${ }^{\circ}$ Brix & $P$ value & $\begin{array}{c}\text { Dry matter } \\
(\%)\end{array}$ & $P$ value \\
\hline \multirow[t]{4}{*}{ Mos166 } & Uninoculated & 4.51 & & 2.23 & & 55.93 & & 72.45 & & 6.79 & & 6.37 & \\
\hline & PRSV & 3.68 & 0.3229 & 1.84 & 0.4008 & 54.72 & 0.7863 & 71.26 & 0.5094 & 7.73 & 0.0631 & 7.84 & 0.1991 \\
\hline & ZYMV & 4.08 & 0.6101 & 1.87 & 0.4320 & 53.39 & 0.5710 & 71.83 & 0.7277 & 7.00 & 0.6734 & 5.27 & 0.3303 \\
\hline & PRSV+ZYMV & 3.90 & 0.3997 & 1.62 & 0.1292 & 59.09 & 0.4179 & 72.00 & 0.7712 & 6.08 & 0.1046 & 5.42 & 0.3626 \\
\hline \multirow[t]{4}{*}{ Soler } & Uninoculated & 12.70 & & 6.79 & & 65.33 & & 68.79 & & 6.38 & & 6.26 & \\
\hline & PRSV & 12.95 & 0.7990 & 5.86 & 0.0892 & 56.12 & 0.0880 & 67.60 & 0.5770 & 5.58 & 0.1797 & 3.71 & 0.0620 \\
\hline & ZYMV & 11.02 & 0.0319 & 5.88 & 0.0330 & 55.21 & 0.0172 & 66.97 & 0.2740 & 5.57 & 0.0827 & 6.07 & 0.8562 \\
\hline & PRSV+ZYMV & 11.63 & 0.2788 & 6.88 & 0.8802 & 69.82 & 0.3995 & 68.16 & 0.7696 & 5.50 & 0.1430 & 6.88 & 0.6450 \\
\hline \multirow[t]{4}{*}{ Menina } & Uninoculated & 6.83 & & 2.68 & & 47.29 & & 71.01 & & 5.25 & & 3.25 & \\
\hline & PRSV & 5.89 & 0.2832 & 2.56 & 0.7960 & 51.48 & 0.3729 & 70.94 & 0.9715 & 6.15 & 0.0889 & 3.60 & 0.7650 \\
\hline & ZYMV & 5.67 & 0.1336 & 2.41 & 0.5091 & 48.11 & 0.8427 & 70.52 & 0.7678 & 5.10 & 0.7430 & 2.60 & 0.5356 \\
\hline & PRSV+ZYMV & 6.10 & 0.4614 & 2.43 & 0.6349 & 50.75 & 0.5155 & 68.30 & 0.2083 & 4.83 & 0.4251 & 3.05 & 0.8848 \\
\hline \multirow[t]{4}{*}{ Nigerian Local } & Uninoculated & 7.25 & & 3.04 & & 46.67 & & 80.04 & & 4.62 & & 4.09 & \\
\hline & PRSV & 6.16 & 0.1562 & 2.26 & 0.0673 & 48.22 & 0.7057 & 78.94 & 0.5067 & 4.83 & 0.6542 & 4.97 & 0.3961 \\
\hline & ZYMV & 7.20 & 0.9505 & 2.94 & 0.8373 & 55.05 & 0.0661 & 77.85 & 0.2270 & 5.42 & 0.1145 & 5.94 & 0.1058 \\
\hline & PRSV+ZYMV & 6.02 & 0.0919 & 2.38 & 0.1013 & 52.25 & 0.1544 & 79.26 & 0.6158 & 4.85 & 0.5942 & 4.99 & 0.3590 \\
\hline
\end{tabular}

gene for moderate resistance in this cultivar. However, in the field, yield and other traits were negatively affected when 'Soler' was inoculated with ZYMV. 'Soler' was susceptible to PRSV. Our results suggest that visually rating symptom severity in the greenhouse or taking ELISA readings on greenhouse plants are both useful methods for selection for resistance to PRSV and ZYMV. Rating symptom severity would be the more economical option in terms of time and money. Reduction in yield in susceptible genotypes inoculated with PRSV and ZYMV ranged from $35 \%$ to $100 \%$. Inoculated plants of 'Nigerian Local' had lower yields than control plants even though plants exhibited no foliar symptoms of potyvirus and tested negative for both PRSV and ZYMV with ELISA. 'Menina' was unaffected by potyvirus inoculation. This suggests that 'Menina' is a better choice than 'Nigerian Local' as a source of resistance to both viruses. Pyramiding genes for resistance from 'Menina', 'Nigerian Local', and 'Soler' (Pachner et al., 2015) might result in the development of the most long-lasting and highly resistant genotypes.

\section{Literature Cited}

Adsuar, J. and A. Cruz Miret. 1950. Virus diseases of cucumbers in Puerto Rico. Univ. P.R. Agr. Expt. Sta., Río Piedras, Technical Paper No. 6.

Brown, R.N., A. Bolanos-Herrera, J.R. Myers, and M.M. Jahn. 2003. Inheritance of resistance to four cucurbit viruses in Cucurbita moschata. Euphytica 129:253-258, doi: 10.1023/A: 1022224327064 .

Cook, M.T. 1936. Records of virus diseases of plants in Puerto Rico. J. Agr. Univ. P. R. 20:681-684.

Costa, C.P. 1974. Obtenção da abobrinha (Cucurbita moschata Duch. Ex. Poir.) Menina Brasileira com hábito de crescimento tipo moita e com tolerância ao mosaico da melancia. Revista Olericultura 14:21.

Demski, J.W. and J.H. Chalkley. 1972. Effect of watermelon mosaic virus on yield and marketability of summer squash. Plant Dis. Rptr. 56:147-150.
Departamento de Agricultura de Puerto Rico. 2015. Ingreso Bruto de la Agricultura de Puerto Rico. 16 Oct. 2020. <https://estadisticas.pr/files/Inventario/ publicaciones/Depto_Agricola_IngresoBrutoAgricola_AF2014-2015_preliminar.pdfs.

Desbiez, C. and H. Lecoq. 1997. Zucchini yellow mosaic virus. Plant Pathol. 46:809-829, doi: 10.1046/j.1365-3059.1997.d01-87.x.

Escudero, J. 1992. Situación de los virus que afectan a las cucurbitáceas en la costa sur de Puerto Rico, p. 44-51. In: El cultivo de Cucurbitáceas: Memorias del foro técnico, June 26, Lajas, Puerto Rico. Universidad de Puerto Rico, Recinto Universitario de Mayagüez, Estación Experimental Agrícola.

Fletcher, J.D., A.R. Wallace, and B.T. Rogers. 2000. Potyviruses in New Zealand buttercup squash (Cucurbita maxima Duch.): Yield and quality effects of ZYMV and WMV 2 virus infections. N. Z. J. Crop Hort. Sci. 28:17-26, doi: 10.1080/01140671.2000.9514118.

Kumar, N.K.K., C.M. Kalleshwaraswamy, H.R. Ranganath, and B.L. Kashinath. 2008. Role of Aphis gossypii Glover (Aphididae: Homoptera) on temporal and spatial spread of Papaya Ringspot Virus-W on pumpkin (Cucurbita moschata). Pest Mgt. Hort. Ecosyst. 14(1):44-50.

Lecoq, H., G. Wisler, and M. Pitrat. 1998. Cucurbit viruses - The classics and the emerging, p. 126142. In: J.D. McCreight (ed.) Cucurbitaceae '98: Evaluation and Enhancement of Germplasm. ASHS Press, Alexandria, VA.

Lisa, V., G. Boccardo, G. D’Agostino, G. Dellavalle, and M. D'Aquilio. 1981. Characterization of a potyvirus that causes zucchini yellow mosaic. Phytopathology 71:667-672.

Maluf, W.R., W. de M. Moura, I.S. da Silva, and M. Castelo-Branco. 1986. Screening of Cucurbita spp. accessions for resistance to Watermelon mosaic virus-1. Brasil. J. Genet. 9(1):161-167.

McGuire, R.G. 1992. Reporting of objective color measurements. HortScience 27(12):1254 1255, doi: 10.21273/HORTSCI.27.12.1254.

McPhail-Medina, R., L. Wessel-Beaver, and J.C.V. Rodrigues. 2012. Inheritance of resistance to Papaya ringspot virus in tropical pumpkin is controlled by at least two genes, p. 697-701. In: S. Sari, I. Solmaz, and V. Aras (eds.). Proceedings of the Xth EUCARPIA Meeting on Genetics and Breeding of Cucurbitaceae, 15-18 Oct. 2012, Antalya, Turkey. Çukurova University, Adana, Turkey.

Miranda-Vélez, M.A., L. Wessel-Beaver, and J.C.V. Rodrigues. 2019. Non-transmission of
ZYMV and PRSV through Resistant Cucurbita moschata Genotypes 'Nigerian Local' and 'Menina'. Cucurbit Genet. Coop. Rpt. 42:3739.

Munger, H.M. and R. Provvidenti. 1987. Inheritance of resistance to Zucchini Yellow Mosaic Virus in Cucurbita moschata. Cucurbit Genet. Coop. Rpt. 10:80-81.

Nascimento, I.R. do, L.B. dos Santos, R. de A. Sarmento, A. dos R. Figueira, G.I.S. de Oliveira, and R.W. de S. Aguiar. 2012. Phenotypic reaction of Cucurbita spp. Genotypes to Pappaya [sic] ringspot virus, watermelon strain PRSV-W. Biosci. J. 28(2):191-197.

Olarte-Castillo, X.A., G. Fermin, J. Tabima, Y. Rojas, P.F. Tennant, M. Fuchs, R. Sierra, A.J. Bernal, and S. Restrepo. 2011. Phylogeography and molecular epidemiology of Papaya ringspot virus. Virus Res. 159(2):132-140, doi: 10.1016/j.virusres.2011.04.011.

Pacheco, D.A., J.A.M. Rezende, and S.M. de S. Piedade. 2003. Biomass, virus concentration, and symptomology of cucurbits infected by mild and severe strains of Papaya ringspot virus. Sci. Agr. 60(4):691-698, doi: 10.1590/ S0103-90162003000400013.

Pachner, M., H.S. Paris, and T. Lelley. 2011. Genes for resistance to Zucchini yellow mosaic in tropical pumpkin. J. Hered. 102:330-335, doi: 10.1093/jhered/esr006.

Pachner, M., H.S. Paris, J. Winkler, and T. Lelley. 2015. Phenotypic and marker-assisted pyramiding of genes for resistance to zucchini yellow mosaic virus in oilseed pumpkin (Cucurbita pepo). Plant Breed. 134:121-128, doi: 10.1111/pbr.12219.

Paris, H.S. and S. Cohen. 2000. Oligogenic inheritance for resistance to Zucchini yellow mosaic virus in Cucurbita pepo. Ann. Appl. Biol. 136:209-214, doi: 10.1111/j.1744-7348.2000. tb00027.x.

Paris, H.S., S. Cohen, Y. Burger, and R. Yoseph. 1988. Single-gene resistance to zucchini yellow mosaic virus in Cucurbita moschata. Euphytica 37:27-29, doi: 10.1007/BF00037219.

Paz-Carrasco, L. and L. Wessel-Beaver. 2002. Survey of cucurbit viruses in Puerto Rico, p. 256-264. In: D.N. Maynard (ed.). Cucurbitaceae. ASHS Press, Alexandria, VA.

Provvidenti, R., D. Gonsalves, and H.S. Humaydan. 1983. The occurrence of zucchini yellow mosaic virus in the United States. Cucurbit Genet. Coop. Rpt. 6:99. 
Provvidenti, R., D. Gonsalves, and H.S. Humaydan. 1984. Occurrence of Zucchini yellow mosaic virus in cucurbits from Connecticut, New York, Florida, and California. Plant Dis. 68(5):443-446.

Rezende, J.A.M., D.A. Pacheco, and A.F. Iemma. 1999. Efeitos da premunização da abóbora 'Menina Brasiliera' con estirpes fracas do virus-do-mosaico-do-mamoeiro-estirpe melancia. Pesqui. Agropecu. Bras. 34(8):1481-1489, doi: 10.1590/S0100-204X1999000800021.
Rodrigues, J.C.V., I. Quintero-Lopez, and L. WesselBeaver. 2012. Potyviridae as a major challenge to growing cucurbits in Puerto Rico, p. 786-790. In: S. Sari, I. Solmaz, and V. Aras (eds.). Proceedings of the Xth EUCARPIA Meeting on Genetics and Breeding of Cucurbitaceae, 15-18 Oct. 2012, Antalya, Turkey. Çukurova University, Adana, Turkey.

Tripathi, S., J.Y. Suzuki, S.A. Ferreira, and D. Gonsalves. 2008. Papaya ringspot virus-P: Characteristics, pathogenicity, sequence vari- ability and control. Mol. Plant Pathol. 9:269280, doi: 10.1111/j.1364-3703.2008.00467.x.

Wessel-Beaver, L. and J.C.V. Rodrigues. 2016. Sources of variation in ELISA tests used to quantify ZYMV and PRSV resistance in Cucurbita moschata, p. 170-173. In: E.U. Kozik and H.S. Paris (eds.). Proceedings of Cucurbitaceae 2016, the XIth EUCARPIA Meeting on Genetics and Breeding of Cucurbitaceae, July 24 28, 2018, Warsaw, Poland. Wydawnictwo SIGMA Sp. J., Skierniewice, Poland. 